\title{
Changes in physicochemical property and lactic acid bacterial community during kimchi fermentation at different temperatures
}

\author{
Hee Yul Lee ${ }^{1}$ Md. Azizul Haque ${ }^{1,2} \cdot$ Kye Man Cho $^{1}$ \\ Received: 26 July 2020 / Accepted: 16 November 2020 / Published Online: 31 December 2020 \\ (C) The Korean Society for Applied Biological Chemistry 2020
}

\begin{abstract}
This study aimed to investigate the change in physicochemical properties and lactic acid bacterial communities during kimchi fermentation at different temperatures $(8,15$, and 25 ${ }^{\circ} \mathrm{C}$ ) using two molecular genetics approaches, multiplex polymerase chain reaction and $16 \mathrm{~S}$ rRNA gene sequencing. The $\mathrm{pH}$ during fermentation at 8,15 , and $25^{\circ} \mathrm{C}$ decreased from 6.17 on the initial fermentation day to $3.92,3.79$, and 3.48 after 54,30 , and 24 days of fermentation, respectively, while the acidity increased from $0.24 \%$ to $1.12,1.35$, and $1.54 \%$, respectively. In particular, the levels of lactic acid increased from $3.74 \mathrm{~g} / \mathrm{L}$ on the initial day (day 0) to $14.43,20.60$, and $27.69 \mathrm{~g} / \mathrm{L}$ during the fermentation after 24,18 , and 12 days at 8,15 , and $25^{\circ} \mathrm{C}$, respectively, after that the lactic acid concentrations decreased slowly. The predominance of lactic acid bacteria (LAB) in the fermented kimchi was dependent on fermentation stage and temperature: Lactobacillus sakei appeared during the initial stage and Leuconsotoc mesenteroides was observed during the optimum-ripening stage at 8,15 , and $25^{\circ} \mathrm{C}$. Lac. sakei and Lactobacillus plantarum grew rapidly in kimchi produced at 8, 15, and $25{ }^{\circ} \mathrm{C}$. In addition, Weissella koreensis first appeared at days 12,9 , and 6 at 8,15 , and $25^{\circ} \mathrm{C}$ of fermentation, respectively. This result suggests that $\mathrm{LAB}$ population dynamics are rather sensitive to environmental conditions, such as $\mathrm{pH}$, acidity, salinity, temperature, and chemical factors including free sugar and organic acids.
\end{abstract}

Kye Man Cho $(\bowtie)$

E-mail:kmcho@gntech.ac.kr

${ }^{1}$ Department of Food Science, Gyeongnam National University of Science and Technology, Jinju 52725, Republic of Korea

${ }^{2}$ Department of Biochemistry \& Molecular Biology, Hajee Mohammad Danesh Science \& Technology University, Dinajpur 5200, Bangladesh

This is an Open Access article distributed under the terms of the Creative Commons Attribution Non-Commercial License (http://creativecommons. org/licenses/by-nc/3.0/) which permits unrestricted non-commercial use, distribution, and reproduction in any medium, provided the original work is properly cited.
Keywords Fermentation temperatures - Kimchi $\cdot$ Lactic acid bacteria - Microbial diversity · Multiplex-polymerase chain reaction · Organic acids

\section{Introduction}

Kimchi is a popular side dish in Korea. During the last three decades, many genera and species of microorganisms found in kimchi have been isolated and reported. The microorganisms in kimchi were actively investigated, for the first time, in a study by Mheen and Kwon [1]. Reportedly, the microorganisms involved in kimchi fermentation included approximately 200 species of bacteria and several yeasts [2]. In fact, the major microorganisms responsible for kimchi fermentation are lactic acid bacteria (LAB). Previously, the LAB that were isolated and identified from fermented kimchi included: Leuconsotoc citreum, Leuconsotoc gasicomitatum, Leuconsotoc mesenteroides, Lactobacillus brevis, Lactobacillus curvatus, Lactobacillus plantarum, Lactobacillus sakei, Lactococcus lactis, Pediococcus pentosaceus, and Weissella Korenesis etc. [3-10].

The common quality indices of kimchi are $\mathrm{pH}$ and acidity, which are affected by a number of factors during fermentation $[1,5]$. The important factors that affect kimchi fermentation are microorganisms, temperature, oxygen level, $\mathrm{pH}$, salt concentration, fermentable carbohydrates, and other available nutrients or any inhibitory compounds in the raw materials used [4]. However, the key factor that affects and controls the fermentation of Chinese cabbage kimchi, has been reported to be fermentation temperature [11]. In fact, the characters of kimchi originate from the action of LAB during fermentation.

Molecular ecological studies have received increasing attention for exploring the microbial diversity in kimchi including polymerase chain reaction (PCR) with a strain-specific primer [5], sodium dodecyl sulfate polyacrylamide gel electrophoresis [12], PCR-denaturing gradient gel electrophoresis (DGGE) [9], genome- 
probing microarray [13], and 16S rRNA gene sequence [6-8,14]. In particular, a multiplex PCR method allows the simultaneous amplification of more than one target sequence in a single PCR reaction, which saves considerable time and effort and decreases the number of reactions that need to be performed to assess the possible presence of microorganisms in the food $[5,15,16]$.

Increasing our knowledge regarding the microbial communities in kimchi during fermentation is an important goal to food microbiologists, not only to understand the precise mechanism of kimchi fermentation but also to control the fermentation process for quality-controlled production of kimchi in industry. Also, several researchers have reported correlations between the microbial community and fermentation environment in kimchi ecosystem [17-19]. Previously, we designed and reported speciesspecific primers for specific detection and identification of each LAB species [5] during kimchi fermentation. In this study, we tried to investigate that the characteristics of kimchi fermentation through changes in the physicochemical properties (including $\mathrm{pH}$, acidity, reducing sugar, and salinity), organic acid contents, and LAB community during kimchi fermentation at different fermentation temperature of 8,15 , and $25^{\circ} \mathrm{C}$.

\section{Materials and Methods}

\section{Bacterial strains and growth media}

Reference LAB were collected from the Korean Type Culture Collection, Korean Culture Center of Microorganisms, and Korean Agricultural Culture Collection [5]. The LAB were grown overnight at $30^{\circ} \mathrm{C}$ in Lactobacilli MRS broth (MRS, Difco, Becton Dickinson Co., Sparks, MD, USA). Escherichia coli DH5 $\alpha$ and recombinant Esc. coli cells were cultured in LuriaBertani broth (Difco, Becton Dickinson Co.) media containing the appropriate antibiotics (ampicillin, $50 \mu \mathrm{g} / \mathrm{mL}$ ) at $37^{\circ} \mathrm{C}$.

\section{Preparation of $\boldsymbol{k i m c h i}$}

Kimchi (3 kg) was obtained from Jonggajib (DaeSang FNF Co., Geochang-gun, Gyeongnam-do, Korea) in Geochang-gun, Korea. A kimchi sample $(1 \mathrm{~kg})$ was placed in a glass jar with a cap and fermented at either $8 \pm 2,15 \pm 1$, and $25 \pm 1{ }^{\circ} \mathrm{C}$.

\section{pH and acidity}

This procedure was adapted as previously described by Cho et al. [5]. Kimchi samples were blended and the $\mathrm{pH}$ was measured with a pH meter (MP220, pH meter, UK). To estimate the acidity, 20 $\mathrm{mL}$ of kimchi filtrate was titrated with $0.1 \mathrm{~N} \mathrm{NaOH}$ at $\mathrm{pH} 8.2 \pm 0.2$. The $\mathrm{pH}$ and acidity measurements were performed in triplicate. The acidity was calculated as follows: Acidity (\%, as lactic acid) $=0.009 \times \mathrm{mL}$ of $0.1 \mathrm{~N} \mathrm{NaOH} \times \mathrm{F} \times 100 /$ Sample $(\mathrm{mL}), \mathrm{F}$ : factor of $0.1 \mathrm{~N} \mathrm{NaOH}$.

\section{Salinity and reducing sugar}

Kimchi samples were blended and after filtered to collect the fluid portion and the salinity was measured with a salt meter (Atago Co., Tokyo, Japan). Reducing sugar in kimchi filtrate was measured with the Dinitro-salicylate method [20].

\section{Organic acids}

High performance liquid chromatography (HPLC) was performed in order to determine the organic acids present during fermentation of kimchi. A $5 \mathrm{~mL}$ sample of the culture was collected and centrifuged. One milliliter of supernatant was filtered through a 0.45- $\mu \mathrm{m}$ Minipore PVDF filter (Schleicher \& Schuell, GmbH, Dassel, Germany) for HPLC analysis. Injection volume was $10 \mu \mathrm{L}$ of the sample. The analysis of organic acids was carried out using HPLC (Perkin-Elmer 200 series, Perkin-Elmer Co., Norwalk, CT, USA) with a TSKgel ODS-100V column $(4.6 \times 250 \mathrm{~mm}$, $5 \mu \mathrm{m}$, Tosoh Corp., Tokyo, Japan). The $0.1 \%$ phosphoric acid $\left(\mathrm{H}_{3} \mathrm{PO}_{4}\right)$ was eluted with a flow rate of $1 \mathrm{~mL} / \mathrm{min}$ at $40{ }^{\circ} \mathrm{C}$. The various organic acids were measured at $210 \mathrm{~nm}$ using a UV detector (Perkin-Elmer UV 200 series, Perkin-Elmer Corp.).

Total LAB cell numbers and isolation of LAB from kimchi One $\mathrm{mL}$ of each blended kimchi sample was diluted in $9 \mathrm{~mL}$ of sterile $0.85 \%$ physiological saline. Aliquots of $1 \mathrm{~mL}$ were serially diluted tenfold using the $0.85 \%$ physiological saline, and $100 \mu \mathrm{L}$ samples were spread on MRS agar plates and incubated at $30{ }^{\circ} \mathrm{C}$ for $48 \mathrm{~h}$. Ninety-six colonies were randomly selected from the total viable $\mathrm{LAB}$ cells on MRS agar plates. The number of cells in each specific LAB isolate was calculated as previously described by Cho et al. [5]. Each specific LAB was calculated as follows: Each of specific $\mathrm{LAB}$ viable cells $(\log \mathrm{CFU} / \mathrm{mL})=$ (detection of each of specific LAB colonies by multiplex PCR or $16 \mathrm{~S}$ rRNA gene sequencing $\div$ isolated 96 colonies $) \times$ total $\mathrm{LAB}$ viable cells on MRSA.

\section{Extraction of genomic DNA from isolated LAB}

Genomic DNA was extracted by a method described in total DNA extraction G-spin ${ }^{\mathrm{TM}}$ Genomic DNA Extraction Kit (iNtRON Biotechnology, Suwon, Korea), or by the method of boiling and vortexing bacterial pellets for $10 \mathrm{~min}$ at $80^{\circ} \mathrm{C}$. The extracted DNA was used as a template for the multiplex PCR.

Primer, multiplex PCR reaction, and agarose gel electrophoresis Ten species-specific primers were designed for the identification of Leu. carnosum, Leu. mesenteroides, Lac. brevis, Lac. plantarum, Lac. pentosus, Lac. sakei, Lac. lactis, Ped. pentosaceus, Wei. confusa, and Wei. korenesis, and multiplex PCR was performed as previously described [5]. PCR of 16S rDNA genes were amplified and these sequences were analyzed as previously described [21,22]. 
16S rRNA PCR, transformation, and sequence analysis

LAB isolates not identified by multiplex PCR were subjected to further identification via $16 \mathrm{~S}$ rRNA gene sequencing. The PCR primers used to amplify 16S rRNA gene fragments were the universal primers (Forward, 5-CGGAGAGTTTPATCCTPG-3; reverse, 5-TACGGCTACCTTPTTAGCGAC-3). PCR of 16S rDNA genes were amplified and these sequences were analyzed as previously described [21].

\section{Results}

Change in $\mathrm{pH}$ and acidity during kimchi fermentation at different temperatures

The changes in $\mathrm{pH}$ and acidity in the kimchi during fermentation at 8,15 , and $25^{\circ} \mathrm{C}$ are shown in Fig. 1. In the case of kimchi fermentation at $8{ }^{\circ} \mathrm{C}$, sharp decreases in $\mathrm{pH}$ were observed during the first 15 days; thereafter, the $\mathrm{pH}$ values were moderately decreased from 15 to 21 days, while the $\mathrm{pH}$ values were negligibly increased from 21 to 54 days. Overall, the $\mathrm{pH}$ decreased from 6.17 (0 day of fermentation) to 4.16 after 54 days of fermentation. On the other hand, the acidity in the kimchi during fermentation gradually increased for 24 days; thereafter, a negligible increase was observed after 54 days. In total, the acidity increased from 0.24 to $1.14 \%$ in the kimchi after 54 days of fermentation (Fig. 1A). The $\mathrm{pH}$ was dramatically decreased within 9 days, and negligibly decreased thereafter until 30 days of fermentation at $15{ }^{\circ} \mathrm{C}$. Overall, the initial $\mathrm{pH}$ decreased from 6.17 to 3.92 after 30 days of fermentation. However, the acidity sharply increased until day 15 and negligibly increased until 30 days of fermentation. In total, the initial (day 0) acidity of 0.24 was increased to $1.35 \%$ at the end of fermentation (30 days) (Fig. 1B). Similarly, for kimchi fermentation that proceeded at $25^{\circ} \mathrm{C}$, the $\mathrm{pH}$ sharply decreased until 6 days, slowly decreased from 6 to 9 days and remained almost unchanged until 24 days of fermentation. The $\mathrm{pH}$ decreased from 6.17 ( 0 day) to 3.48 at the end of fermentation ( 24 days). In contrast, the acidity was markedly increased until 6 days and slowly increased from 6 to 9 days, then negligibly increased until 24 days. Overall, the acidity increased from 0.24 to $1.54 \%$ in kimchi after 24 days of fermentation (Fig. 1C).

\section{Change in salinity and reducing sugar during kimchi} fermentation at different temperatures

The reduction of salinity and reducing sugar during fermentation of kimchi at 8,15 , and $25^{\circ} \mathrm{C}$ is described in Fig. 2. In the case of fermentation at $8{ }^{\circ} \mathrm{C}$, the salinity $(3.3 \%)$ remained constant until 15 days of fermentation; thereafter, it decreased slowly from 3.3 to $2.7 \%$ after 54 days of fermentation. Similar to salinity, the reducing sugar concentration $(43.07 \mathrm{~g} / \mathrm{L})$ remained almost unchanged until 15 days of fermentation, and rapidly decreased thereafter to $15.25 \mathrm{~g} / \mathrm{L}$ at the end of fermentation (Fig. 2A). The salinity gradually decreased from 3.3 to $2.6 \%$ at the end of
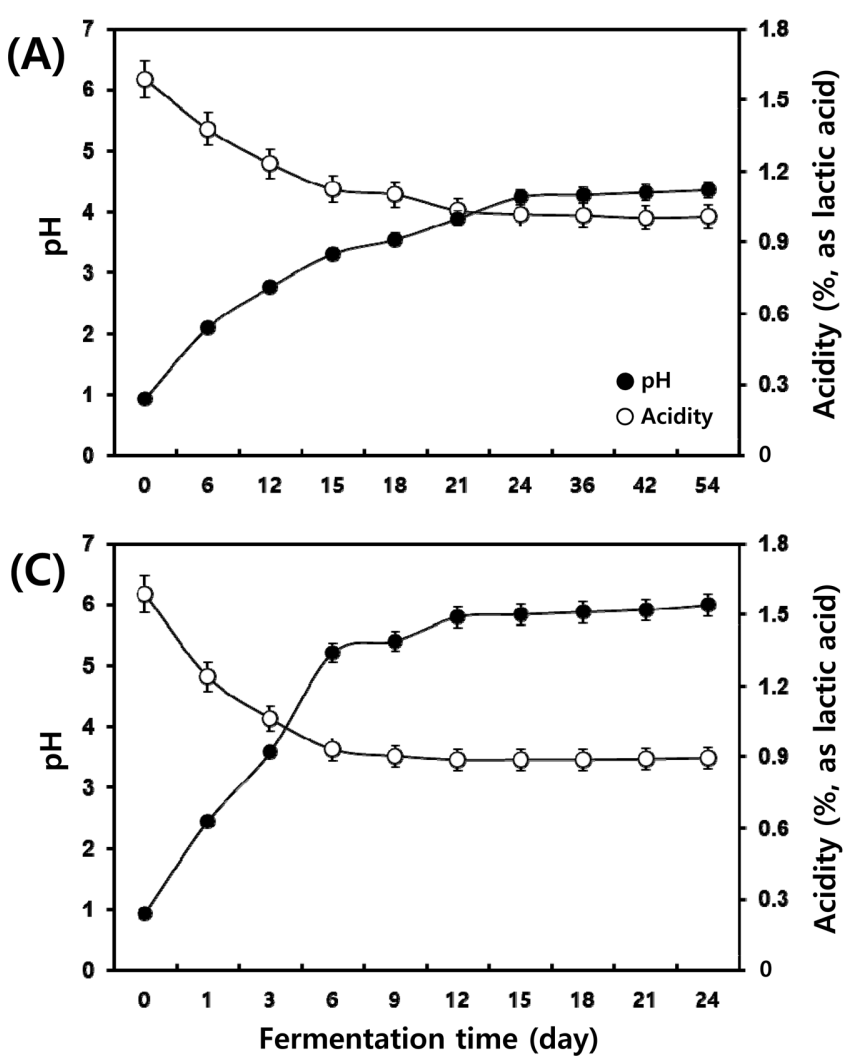

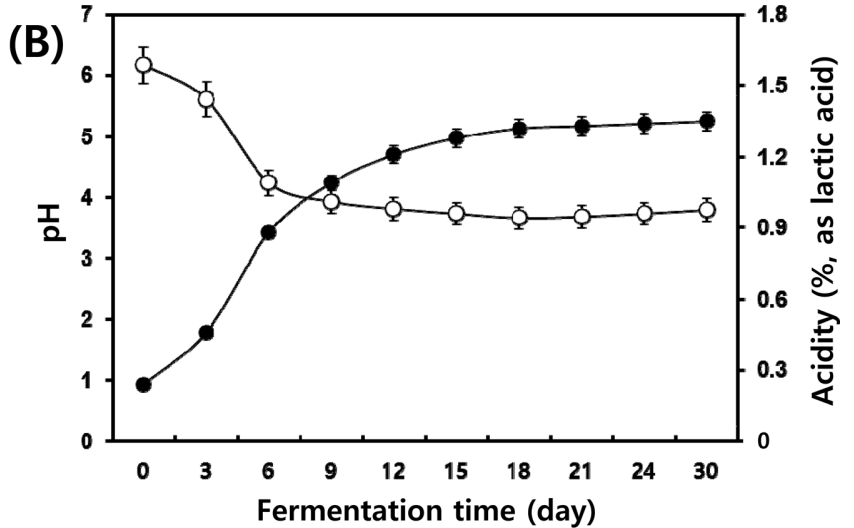

Fig. 1 Change in $\mathrm{pH}$ and acidity during kimchi fermentation at 8 (A), 15 (B), and $25^{\circ} \mathrm{C}(\mathrm{C})$ for 24,30 , and 54 days, respectively. Values indicate the mean of three replications 

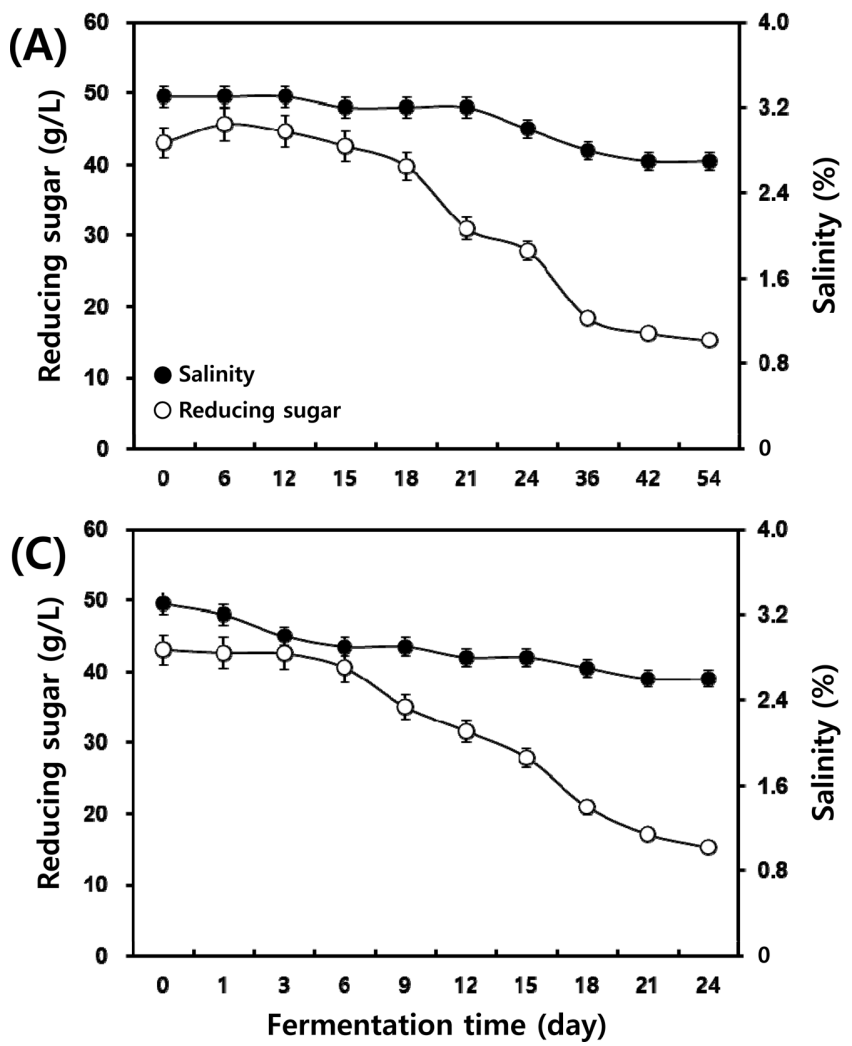

fermentation (30 days) during kimchi fermentation at $15^{\circ} \mathrm{C}$. In addition, the reducing sugar concentration $(43.07 \mathrm{~g} / \mathrm{L})$ gradually decreased for 15 days, and sharply decreased thereafter to $15.41 \mathrm{~g} / \mathrm{L}$ at the end of fermentation (Fig. 2B). Similarly, in the case of fermentation at $25{ }^{\circ} \mathrm{C}$, the salinity and reducing sugar concentration decreased from the initial 3.3 and 43.07 to 2.6 and $15.31 \mathrm{~g} / \mathrm{L}$ at the end of fermentation (24 days) (Fig. 2C).

\section{Change in organic acid contents during kimchi fermentation} at different temperatures

During kimchi fermentation, the total organic acids increased gradually until 12,21 , and 24 days; after that, the total organic acid concentration decreased slowly. In particular, the levels of lactic acid increased rapidly during kimchi fermentation. The lactic acid concentration increased from 3.74 at 0 day of fermentation to $10.53,18.35,20.5 \mathrm{~g} / \mathrm{L}$ at the end of fermentation (54, 30, and 24 days) at $8,15,25^{\circ} \mathrm{C}$, respectively (Fig. 3). The concentration of succinic acid, acetic acid, maleic acid, and citric acid increased slightly during kimchi fermentation at $8{ }^{\circ} \mathrm{C}$, but in the case of oxalic acid concentration unchanged (Fig. 3A). In the case of kimchi fermentation at $15{ }^{\circ} \mathrm{C}$, the concentration of succinic acid and acetic acid increased slightly, but the levels of oxalic acid, malic acid, citric acid negligibly increased at the end of fermentation (Fig. 3B). During kimchi fermentation at $25{ }^{\circ} \mathrm{C}$, the concentration of succinic acid, oxalic acid, and acetic acid increased slightly, but the values of maleic acid and citric acid a little increased at the end of fermentation (Fig. 3C).

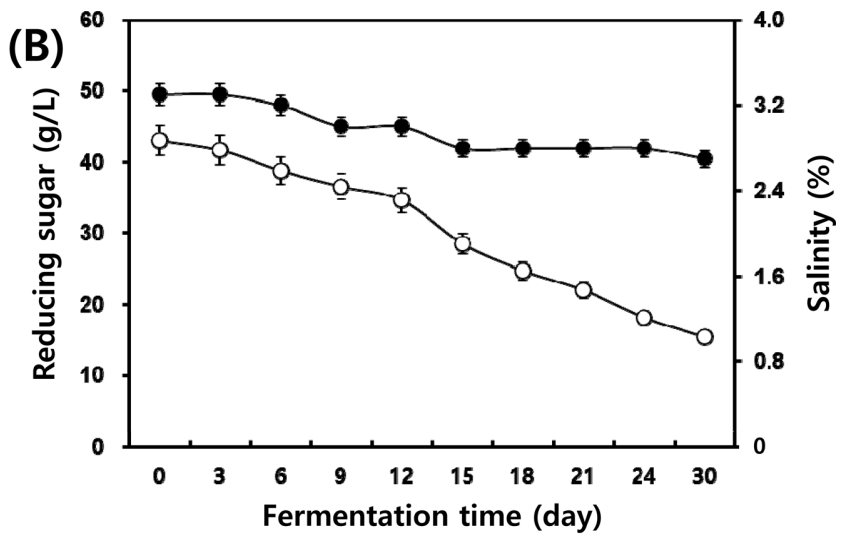

Fig. 2 Change in reducing sugar content and salinity during kimchi fermentation at 8 (A), 15 (B), and 25 (C) for 24, 30, and 54 days, respectively. Values indicate the mean of three replications

\section{Change in LAB population during kimchi fermentation at different temperatures}

Changes in specific types of LAB were observed during kimchi fermentation using multiplex PCR and 16S rRNA sequence analysis. A sample from each of the 96 colonies was analyzed. The changes in the $\mathrm{LAB}$ population during fermentation of kimchi at 8,15 , and $25^{\circ} \mathrm{C}$ are shown in Table 1 . The isolates included five Leuconostoc species (Leu. carnosum, Leu. citreum, Leu. gasicomitatum, Leu. gelidum, and Leu. mesenteroides), five Lactobacillus species (Lac. brevis, Lac. curvatus, Lac. plantarum, Lac. pentosus, and Lac. sakei), one Lactococcus species (Lac. lactis), one Pediococcus species (Ped. pentosaceus), and two Weissella species (Wei. confusa and Wei. koreenesis).

In the case of initial fermentation ( 0 day), the lactic acid bacterial community included Leu. carnosum ( 0.32 for log CFU/ $\mathrm{mL})$, Leu. citreum (0.71), Leu. mesenteroides (0.38), Lac. plantarum (0.16), Lac. sakei (1.59), Lac. lactis (1.26), Ped. pentosaceus (0.16), and Wei. confusa (0.65) (Table 1). As fermentation proceeded at $8{ }^{\circ} \mathrm{C}$, the levels of Leu. carnosum, Leu. citreum, Lac. lactis, and Wei. confusa decreased until 12 days (0.08), 15 days (0.28), and 18 days (0.09), respectfully; after that, they were not detected during fermentation. Leu. mesenteroides population increased greatly until 12 days (3.37), and then decreased. The Lac. plantarum concentration increased slowly to a maximum of 1.08 at 18 days, after which it decreased gradually until the end of fermentation (54 days) to $0.31 \log \mathrm{CFU} / \mathrm{mL}$. The level of $\mathrm{Lac}$. sakei increased greatly until day 36 (7.78), and then decreased 

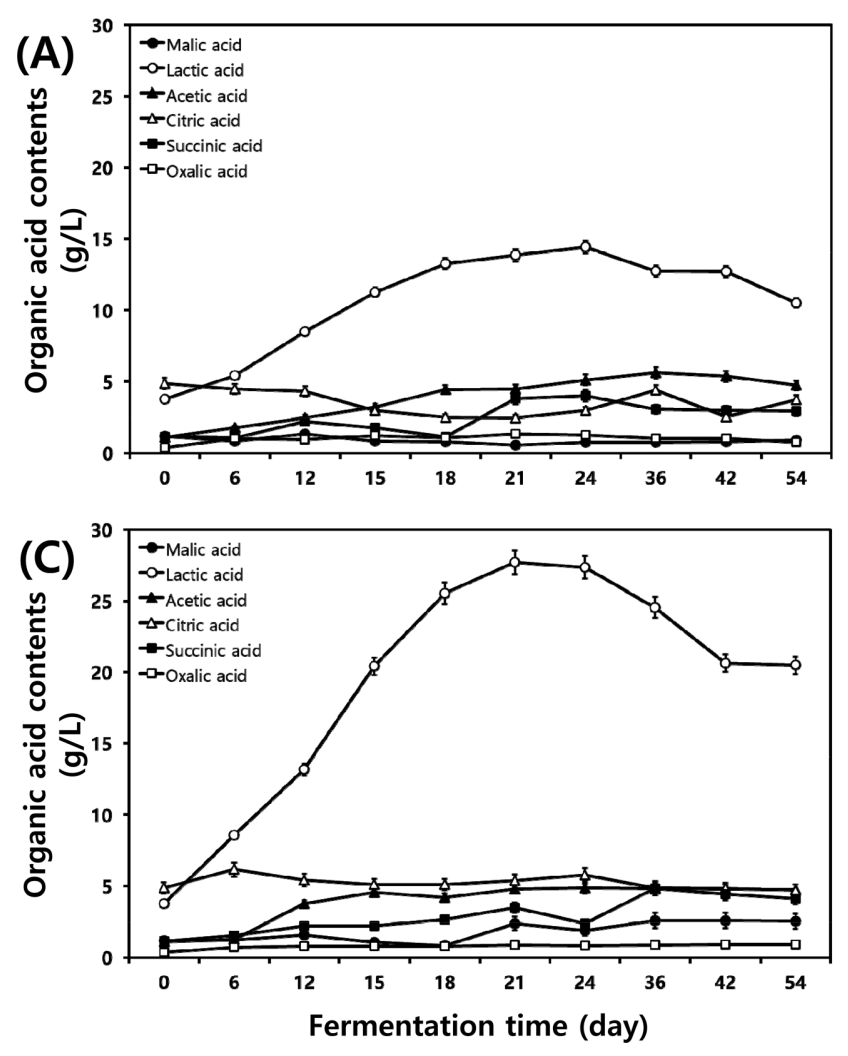

until 54 days (5.43) (Table 1). In the case of fermentation at $15^{\circ} \mathrm{C}$, the cells of Leu. carnosum, Leu. citreum, Lac. lactis, and Wei. confusa decreased until 9 days (0.36), 15 days (0.28), 15 days $(0.83)$, and 9 days $(0.24)$, respectively, and were not detected during fermentation after these time points. The Leu. mesenteroides increased until 9 days (3.24), after which they decreased until 24 days (0.26) of fermentation. On the other hand, the Lac. plantarum greatly increased until 21 days (6.6), and then decreased. Lac. sakei decreased greatly until 3 days (0.93) and increased to a maximum of $3.54 \log \mathrm{CFU} / \mathrm{mL}$ at 9 days, after which it decreased until 24 days (0.26). On the other hand, Leu. gasicomitatum first appeared at 12 days, increased to a maximum of 1.68 at 24 days, and afterwards decreased to $0.73 \log \mathrm{CFU} / \mathrm{mL}$ at the end of fermentation (Table 1). During fermentation at $25^{\circ} \mathrm{C}$, the numbers of Leu. carnosum, Lac. lactis, Wei. confusa and Leu. citreum, decreased until 3 days $(0.22,0.44$, and $0.22 \log \mathrm{CFU} / \mathrm{mL}$, respectively) and 6 days $(0.25)$ and after that they were not detected during fermentation. However, the Leu. gasicomitatum first appeared at 6 days, increased to a maximum of $1.45 \log$ CFU/ $\mathrm{mL}$ at 9 days, and then decreased at 21 days (0.25). The Leu. mesenteroides increased until 1 day (2.57), then decreased until 15 days (0.56) of fermentation and were not detected again during fermentation. On the other hand, the Lac. plantarum increased greatly at day 12 (8.63) and later decreased gradually until the end of fermentation (6.31). The Loc. sakei population increased to a maximum of $2.35 \log \mathrm{CFU} / \mathrm{mL}$ at 1 day, after which it decreased until 12 days (0.27) and was not detected again during

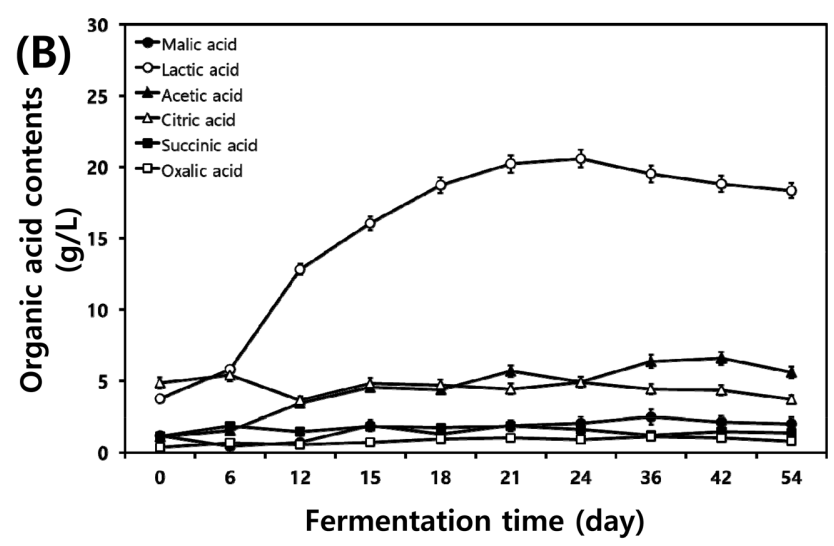

Fig. 3 Change in organic acid content during kimchi fermentation at 8 (A), 15 (B), and 25 (C) for 24, 30, and 54 days, respectively. Values indicate the mean of three replications

fermentation. Importantly, Wei. koreenesis first appeared at 12 (0.08 $\log \mathrm{CFU} / \mathrm{mL}), 9(0.48)$, and 6 days (0.5) and then increased markedly until 54 (2.88), 30 (3.86), and 24 days (2.57) of fermentation (Table 1).

\section{Discussion}

Without starter cultures, kimchi is made through lactic acid fermentation of Chinese cabbage at low temperatures to ensure proper ripening and preservation. Because kimchi fermentation is changed from an initial open ecosystem to a later closed ecosystem, each batch of fermented kimchi has a different community of bacteria depending on fermentation conditions and ingredients. Lee et al. [17] suggested that the microbial community differed through fermentation conditions (such as salt and sugar concentration, major ingredient, fermentation temperature, and fermentation period), fermentation properties (including $\mathrm{pH}$, acidity, salt and sugar concentration), and different kimchi samples (household, commercial, and regional sources). Recently, Lee et al. [19] reviewed that kimchi fermentation are carried out by complex microbial metabolisms to produce diverse metabolites including lactate, acetate, $\mathrm{CO}_{2}$, ethanol, mannitol, amino acids, formate, malate, diacetyl, acetion, and 2,3-butanediol. This study set out to explore the diversity and community dynamics of LAB during kimchi fermentation at different temperatures using our previously developed multiplex PCR assay method. To understand 
Table 1 Change in the lactic acid bacterial population during kimchi fermentation at 8 , 15 , and $25^{\circ} \mathrm{C}$ for 24,30 , and 54 days, respectively

\begin{tabular}{|c|c|c|c|c|c|c|c|c|c|c|}
\hline Temperature & \multicolumn{10}{|c|}{ Specific $^{\mathrm{a}}$ and total ${ }^{\mathrm{b}}$ viable LAB cell numbers* $(\log \mathrm{CFU} / \mathrm{mL})$} \\
\hline \multirow{2}{*}{ Temp. $8{ }^{\circ} \mathrm{C}$} & \multicolumn{10}{|c|}{ Fermentation time (day) } \\
\hline & 0 & 6 & 12 & 15 & 18 & 21 & 24 & 36 & 42 & 54 \\
\hline \multicolumn{11}{|l|}{ Leuconostoc } \\
\hline Leu. carnosum ${ }^{\dagger}$ & $0.32 \pm 0.02$ & $0.31 \pm 0.02$ & $0.08 \pm 0.00$ & $n d^{c}$ & nd & nd & nd & nd & nd & nd \\
\hline Leu. citreum & $0.71 \pm 0.04$ & $0.47 \pm 0.02$ & $0.44 \pm 0.02$ & $0.28 \pm 0.01$ & nd & nd & nd & nd & nd & nd \\
\hline Leu. gasicomitatum & nd & nd & nd & $0.37 \pm 0.02$ & $0.48 \pm 0.02$ & $0.41 \pm 0.02$ & $0.47 \pm 0.02$ & $0.26 \pm 0.01$ & nd & nd \\
\hline Leu. gelidum & nd & nd & $0.08 \pm 0.00$ & nd & nd & nd & nd & nd & nd & nd \\
\hline Leu. mesenteroides ${ }^{\dagger}$ & $0.38 \pm 0.02$ & $2.88 \pm 0.14^{d}$ & $3.37 \pm 0.17$ & $1.72 \pm 0.09$ & $1.16 \pm 0.06$ & $1.54 \pm 0.08$ & $1.18 \pm 0.06$ & $1.28 \pm 0.06$ & $1.36 \pm 0.07$ & $1.43 \pm 0.07$ \\
\hline \multicolumn{11}{|l|}{ Lactobacillus } \\
\hline Lac. brevis ${ }^{\dagger}$ & nd & nd & nd & $0.28 \pm 0.01$ & nd & $0.31 \pm 0.02$ & $0.11 \pm 0.01$ & nd & $0.37 \pm 0.02$ & $0.43 \pm 0.02$ \\
\hline Lac. curvatus & nd & nd & nd & nd & nd & nd & $0.11 \pm 0.01$ & nd & nd & nd \\
\hline Lac. pentosus ${ }^{\dagger}$ & nd & nd & nd & nd & nd & $0.10 \pm 0.01$ & nd & nd & nd & nd \\
\hline Lac. plantarum ${ }^{\dagger}$ & $0.16 \pm 0.00$ & $0.31 \pm 0.02$ & $0.53 \pm 0.03$ & $0.56 \pm 0.03$ & $1.08 \pm 0.05$ & $0.62 \pm 0.03$ & $0.94 \pm 0.05$ & $0.77 \pm 0.04$ & $0.62 \pm 0.03$ & $0.31 \pm 0.02$ \\
\hline Lac. sakei & $1.59 \pm 0.08$ & $2.50 \pm 0.13$ & $3.28 \pm 0.16$ & $4.76 \pm 0.24$ & $5.21 \pm 0.26$ & $5.65 \pm 0.28$ & $6.83 \pm 0.34$ & $7.78 \pm 0.39$ & $6.85 \pm 0.34$ & $5.43 \pm 0.27$ \\
\hline \multicolumn{11}{|l|}{ Lactoccous } \\
\hline Lac. lactis ${ }^{\dagger}$ & $1.26 \pm 0.06$ & $0.71 \pm 0.04$ & $0.18 \pm 0.01$ & $0.28 \pm 0.01$ & nd & nd & nd & nd & nd & nd \\
\hline \multicolumn{11}{|l|}{ Pediococcus } \\
\hline Ped. pentosaceus ${ }^{\dagger}$ & $0.16 \pm 0.01$ & nd & nd & nd & $0.09 \pm 0.00$ & nd & nd & nd & nd & nd \\
\hline \multicolumn{11}{|l|}{ Weissella } \\
\hline Wei. confusa $a^{\dagger}$ & $0.65 \pm 0.03$ & $0.31 \pm 0.02$ & $0.44 \pm 0.02$ & nd & $0.09 \pm 0.00$ & nd & nd & nd & nd & nd \\
\hline Wei. koreensis ${ }^{\dagger}$ & nd & nd & $0.08 \pm 0.00$ & $0.64 \pm 0.03$ & $1.16 \pm 0.06$ & $1.23 \pm 0.06$ & $1.66 \pm 0.08$ & $2.19 \pm 0.11$ & $2.73 \pm 0.14$ & $2.88 \pm 0.14$ \\
\hline Total LAB cells & $5.23 \pm 0.26$ & $7.49 \pm 0.37$ & $8.48 \pm 0.42$ & $8.89 \pm 0.44$ & $9.27 \pm 0.46$ & $9.86 \pm 0.49$ & $11.30 \pm 0.57$ & $12.28 \pm 0.61$ & $11.93 \pm 0.60$ & $10.48 \pm 0.52$ \\
\hline \multirow{2}{*}{ Temp. $15^{\circ} \mathrm{C}$} & \multicolumn{10}{|c|}{ Fermentation time (day) } \\
\hline & 0 & 3 & 6 & 9 & 12 & 15 & 18 & 21 & 24 & 30 \\
\hline \multicolumn{11}{|l|}{ Leuconostoc } \\
\hline Leu. carnosum ${ }^{\dagger}$ & $0.32 \pm 0.02$ & $0.57 \pm 0.03$ & $0.36 \pm 0.02$ & $0.36 \pm 0.02$ & nd & nd & nd & nd & nd & nd \\
\hline Leu. citreum ${ }^{*}$ & $0.71 \pm 0.04$ & $0.93 \pm 0.05$ & $0.62 \pm 0.03$ & $0.60 \pm 0.03$ & $0.76 \pm 0.04$ & $0.28 \pm 0.01$ & nd & nd & nd & nd \\
\hline Leu. gasicomitatum & nd & nd & nd & nd & $0.76 \pm 0.04$ & $0.83 \pm 0.04$ & $1.66 \pm 0.08$ & $1.26 \pm 0.06$ & $1.68 \pm 0.08$ & $0.73 \pm 0.04$ \\
\hline Leu. gelidum & nd & $0.15 \pm 0.01$ & $0.18 \pm 0.01$ & nd & nd & nd & nd & nd & nd & nd \\
\hline Leu. mesenteroides ${ }^{\dagger}$ & $0.38 \pm 0.02$ & $2.30 \pm 0.12$ & $2.67 \pm 0.13$ & $3.24 \pm 0.16$ & $3.17 \pm 0.16$ & $2.83 \pm 0.14$ & $0.98 \pm 0.05$ & $0.28 \pm 0.01$ & $0.26 \pm 0.01$ & nd \\
\hline \multicolumn{11}{|l|}{ Lactobacillus } \\
\hline Lac. brevis ${ }^{\dagger}$ & nd & nd & $0.36 \pm 0.02$ & nd & $0.51 \pm 0.03$ & $0.28 \pm 0.01$ & $0.56 \pm 0.02$ & nd & $0.64 \pm 0.03$ & nd \\
\hline Lac. curvatus & nd & nd & nd & nd & nd & $0.28 \pm 0.01$ & nd & nd & nd & nd \\
\hline Lac. pentosus ${ }^{\dagger}$ & nd & nd & nd & $0.24 \pm 0.01$ & $0.76 \pm 0.01$ & $0.28 \pm 0.01$ & $1.26 \pm 0.06$ & $0.70 \pm 0.04$ & 0 & 0 \\
\hline Lac. plantarum ${ }^{\dagger}$ & $0.16 \pm 0.01$ & $0.57 \pm 0.03$ & $1.96 \pm 0.10$ & $2.78 \pm 0.14$ & $4.32 \pm 0.22$ & $4.65 \pm 0.23$ & $5.41 \pm 0.27$ & $6.60 \pm 0.33$ & $6.21 \pm 0.31$ & $6.45 \pm 0.32$ \\
\hline Lac. sakei $i^{\dagger}$ & $1.59 \pm 0.08$ & $0.93 \pm 0.05$ & $1.59 \pm 0.08$ & $3.54 \pm 0.18$ & $1.24 \pm 0.06$ & $1.10 \pm 0.06$ & $0.70 \pm 0.04$ & $1.4 \pm 0.07$ & $0.26 \pm 0.01$ & nd \\
\hline \multicolumn{11}{|l|}{ Lactoccous } \\
\hline Lac. lactis ${ }^{\dagger}$ & $1.26 \pm 0.06$ & $0.82 \pm 0.04$ & $0.62 \pm 0.03$ & $0.48 \pm 0.02$ & $0.52 \pm 0.03$ & $0.83 \pm 0.04$ & nd & nd & nd & nd \\
\hline \multicolumn{11}{|l|}{ Pediococcus } \\
\hline Ped. pentosaceus ${ }^{\dagger}$ & $0.16 \pm 0.01$ & $0.21 \pm 0.01$ & $0.18 \pm 0.01$ & nd & nd & nd & nd & nd & $0.12 \pm 0.01$ & nd \\
\hline \multicolumn{11}{|l|}{ Weissella } \\
\hline Wei. confusa $a^{\dagger}$ & $0.65 \pm 0.03$ & $0.44 \pm 0.02$ & nd & $0.24 \pm 0.01$ & nd & nd & nd & nd & nd & nd \\
\hline Wei. koreensis ${ }^{\dagger}$ & nd & nd & nd & $0.48 \pm 0.02$ & $1.24 \pm 0.06$ & $1.86 \pm 0.09$ & $2.86 \pm 0.14$ & $3.20 \pm 0.16$ & $3.24 \pm 0.16$ & $3.86 \pm 0.19$ \\
\hline Total LAB cells & $5.23 \pm 0.26$ & $6.92 \pm 0.35$ & $8.54 \pm 0.43$ & $11.48 \pm 0.57$ & $12.04 \pm 0.60$ & $13.22 \pm 0.66$ & $13.43 \pm 0.67$ & $13.44 \pm 0.67$ & $12.41 \pm 0.62$ & $11.04 \pm 0.55$ \\
\hline
\end{tabular}


Table 1 Continued

\begin{tabular}{|c|c|c|c|c|c|c|c|c|c|c|}
\hline \multirow{3}{*}{ Temp. $25^{\circ} \mathrm{C}$} & \multicolumn{10}{|c|}{ Specific $^{\mathrm{a}}$ and total ${ }^{\mathrm{b}}$ viable $\mathrm{LAB}$ cell numbers* $(\log \mathrm{CFU} / \mathrm{mL})$} \\
\hline & \multicolumn{10}{|c|}{ Fermentation time (day) } \\
\hline & 0 & 1 & 3 & 6 & 9 & 12 & 15 & 18 & 21 & 24 \\
\hline \multicolumn{11}{|l|}{ Leuconostoc } \\
\hline Leu. carnosum ${ }^{\dagger}$ & $0.32 \pm 0.02$ & $0.23 \pm 0.01$ & $0.22 \pm 0.01$ & nd & nd & nd & nd & nd & nd & nd \\
\hline Leu. citreum & $0.71 \pm 0.04$ & $0.54 \pm 0.03$ & $0.56 \pm 0.03$ & $0.25 \pm 0.01$ & nd & nd & nd & nd & nd & $\mathrm{Nd}$ \\
\hline Leu. gasicomitatum & nd & nd & nd & $0.88 \pm 0.04$ & $1.45 \pm 0.07$ & $0.82 \pm 0.04$ & $0.7 \pm 0.04$ & $0.52 \pm 0.03$ & $0.25 \pm 0.01$ & nd \\
\hline Leu. gelidum & nd & $0.08 \pm 0.00$ & nd & nd & nd & nd & nd & nd & nd & nd \\
\hline Leu. mesenteroides ${ }^{\dagger}$ & $0.38 \pm 0.02$ & $\mathbf{2 . 5 7} \pm 0.13$ & $2.46 \pm 0.12$ & $1.98 \pm 0.10$ & $0.91 \pm 0.05$ & nd & $0.56 \pm 0.03$ & nd & nd & nd \\
\hline \multicolumn{11}{|l|}{ Lactobacillus } \\
\hline Lac. brevis ${ }^{\dagger}$ & nd & nd & $0.44 \pm 0.02$ & nd & $0.52 \pm 0.03$ & $0.68 \pm 0.03$ & $0.70 \pm 0.04$ & $0.52 \pm 0.03$ & $1.23 \pm 0.06$ & $1.54 \pm 0.08$ \\
\hline Lac. curvatus: & nd & nd & nd & nd & nd & nd & nd & nd & nd & nd \\
\hline Lac. pentosus ${ }^{\dagger}$ & nd & nd & $0.12 \pm 0.01$ & $0.25 \pm 0.01$ & $0.49 \pm 0.02$ & $0.68 \pm 0.03$ & $0.28 \pm 0.01$ & $0.52 \pm 0.03$ & nd & nd \\
\hline Lac. plantarum ${ }^{\dagger}$ & $0.16 \pm 0.01$ & $0.39 \pm 0.02$ & $4.0 \pm 0.20$ & $6.79 \pm 0.34$ & $7.67 \pm 0.38$ & $8.63 \pm 0.43$ & $8.87 \pm 0.44$ & $7.98 \pm 0.40$ & $7.74 \pm 0.39$ & $6.31 \pm 0.32$ \\
\hline Lac. sakei & $1.59 \pm 0.08$ & $2.35 \pm 0.12$ & $2.16 \pm 0.11$ & $1.36 \pm 0.07$ & $0.26 \pm 0.01$ & $0.27 \pm 0.01$ & nd & nd & nd & nd \\
\hline \multicolumn{11}{|l|}{ Lactoccous } \\
\hline Lac. lactis & $1.26 \pm 0.06$ & $0.70 \pm 0.04$ & $0.44 \pm 0.02$ & nd & nd & $0.13 \pm 0.01$ & nd & nd & nd & nd \\
\hline \multicolumn{11}{|l|}{ Pediococcus } \\
\hline Ped. pentosaceus ${ }^{\dagger}$ & $0.16 \pm 0.01$ & nd & nd & nd & nd & nd & nd & nd & nd & nd \\
\hline \multicolumn{11}{|l|}{ Weissella } \\
\hline Wei. confusa ${ }^{\dagger}$ & $0.65 \pm 0.03$ & $0.62 \pm 0.03$ & $0.22 \pm 0.01$ & nd & nd & nd & nd & nd & nd & nd \\
\hline Wei. koreensis ${ }^{\dagger}$ & nd & nd & nd & $0.50 \pm 0.03$ & $1.17 \pm 0.06$ & $1.82 \pm 0.09$ & $2.29 \pm 0.11$ & $2.52 \pm 0.13$ & $2.47 \pm 0.12$ & $2.57 \pm 0.13$ \\
\hline Total LAB cells & $5.23 \pm 0.26$ & $7.48 \pm 0.37$ & $10.62 \pm 0.53$ & $12.01 \pm 0.60$ & $12.47 \pm 0.62$ & $13.03 \pm 0.65$ & $13.40 \pm 0.67$ & $12.06 \pm 0.60$ & $11.69 \pm 0.58$ & $10.42 \pm 0.52$ \\
\hline $\begin{array}{l}\text { Values indicate the mean } \\
\text { The specific LAB was id } \\
\text { The specific LAB was id } \\
\text { Each of specific LAB vial } \\
\text { One ml of each blended } \\
\text { nd: not detected }\end{array}$ & $\begin{array}{l}\text { hree replica } \\
\text { d by multi1 } \\
\text { d by } 16 \mathrm{~S} \text { rl } \\
\text { ls (log CFU } \\
\text { i was serial }\end{array}$ & $\begin{array}{l}\text { ations }(n=3) \\
\text { plex PCR me } \\
\text { RNA sequen } \\
\mathrm{J} / \mathrm{mL})=(\text { dete } \\
\text { lly diluted. D }\end{array}$ & $\begin{array}{l}\text { ethod } \\
\text { ncing analysi } \\
\text { ection of eacl } \\
\text { Dilutions wer }\end{array}$ & $\begin{array}{l}\text { is } \\
\text { h of specific } \\
\text { e plated onto }\end{array}$ & $\begin{array}{l}\text { LAB colonie } \\
\text { o MRSA and }\end{array}$ & $\begin{array}{l}\text { es/isolated } 96 \\
\text { after these }\end{array}$ & incubated at & $\begin{array}{l}\text { total } \mathrm{LAB} \text { vi } \\
30^{\circ} \mathrm{C} \text { for } 48\end{array}$ & iable cells o & MRSA \\
\hline
\end{tabular}

the quality of the kimchi, the physicochemical properties, such as $\mathrm{pH}$, acidity, organic acid profile, salinity and reducing sugar concentration, of kimchi were investigated. The chemical composition of kimchi is different according to the varieties of cabbage and types and amounts of minor ingredients used. In fact, carbohydrates in kimchi raw materials are converted by LAB into metabolites such as organic acids, carbon dioxide, ethanol, and aromatic compounds.

Generally, the best quality of kimchi can be obtained at $\mathrm{pH} 4.2$ to 4.5 and acidity of 1.5 to $2.0 \%$ [1,5]. In this study, kimchi fermented at $8{ }^{\circ} \mathrm{C}$ had a $\mathrm{pH}$ of 4.16 and acidity of $1.14 \%$ at the optimum ripening stage that occurred after 54 days of fermentation. However, in the case of fermentation at $15^{\circ} \mathrm{C}$, the optimum $\mathrm{pH}$ and acidity appeared after 24 days of fermentation. Similarly, in the case of fermentation at $25^{\circ} \mathrm{C}$, the optimum $\mathrm{pH}$ and acidity appeared after 15 days of fermentation. Previously, lactic, acetic, citric, malic, fumaric, succinic, oxalic, tartaric, malonic, maleic, and glycolic acid were identified from kimchi samples. Among the organic acids identified, lactic acid and acetic acid are the major acids that are increased by fermentation [9]. In this study, the concentration of lactic acid, as well as other organic acids, was greatly increased at this fermentation time point. In particular, the concentration of lactic acid increased from 3.74 to $10.53,18.35$, and $20.50 \mathrm{~g} / \mathrm{L}$ at the end of fermentation conducted at 8,15 , and $25^{\circ} \mathrm{C}$, respectively. The results suggested that as the temperature increased, the $\mathrm{pH}$ and reducing sugar was greatly decreased, while acidity and total organic acid were markedly increased during the kimchi fermentation. Therefore, temperature could be a key factor governing the kimchi fermentation. Free sugars play important roles in the taste of kimchi because free sugars are not only sweeteners but also serve as carbon sources for $\mathrm{LAB}$ to produce various products. Free sugars decreased during heterophic lactic acid fermentation of kimchi, while lactate, acetate, and ethanol increased [17].

The predominant LAB species fermented kimchi at different stages and temperatures. Leu. mesenteriodes was present during the immature stage at $8^{\circ} \mathrm{C}(2.88,6,5.36,0.54$ for $\log \mathrm{CFU} / \mathrm{mL}$, days, $\mathrm{pH}$, acidity), and $15^{\circ} \mathrm{C}(2.3,3,5.61,0.46)$ and during the 
optimum-ripening stage at $8{ }^{\circ} \mathrm{C}(3.37,12,4.79,0.71), 15^{\circ} \mathrm{C}(2.67$, $6,4.24,0.88)$, and $25^{\circ} \mathrm{C}(2.57,1,4.82,0.63)$. Lac. sakei was present during the initial stage $(1.59,0,6.17,0.24)$, the overripening stage at $8{ }^{\circ} \mathrm{C}(5.65,21,4.02,1.0)$, and $15^{\circ} \mathrm{C}(3.54,9$, $3.93,1.09)$, and the rancid stage at $8^{\circ} \mathrm{C}(5.43,54,3.92,1.12)$. Lac. plantarum was present during the over-ripening stage at $25^{\circ} \mathrm{C}$ $(4.0,3,4.13,0.92)$ and rancid stage at $15^{\circ} \mathrm{C}(6.45,30,3.79,1.35)$ and $25^{\circ} \mathrm{C}(6.31,24,3.48,1.54)$. These results also suggest that fermentation temperature and acidity are one of the primary determinants of microbial populations in kimchi and that complex microbial succession is not crucial for kimchi fermentation. Generally, Leuconsotoc species typically dominate during the initial fermentation with low acidity at high temperature, while Weissella and Lactobacillus species have the ability to grow under high acidity and low temperatures, indicating that kimchi fermentation temperature and acidity are important determinants of the microbial population [17]. Previously, several studies reported that Leuconsotoc species were the major microorganisms at the beginning of kimchi fermentation and that they reach their highest population during the optimum-ripening period $[5,23]$. Cogan and Jordan [24] reviewed that they only obtained energy by fermentation, always producing lactic acid as all other LAB and $\mathrm{CO}_{2}$, and ethanol or acetate. Therefore, their suggestion that Lac. plantarum was responsible for over-ripening of kimchi has to be further tested by careful studies at several temperatures. Mheen and Kwon [1] showed that Lac. plantarum appeared at 30, 20, and $14{ }^{\circ} \mathrm{C}$, but could not be detected at a lower temperature $\left(5^{\circ} \mathrm{C}\right)$, and similar results were also reported by Lim et al. [25] and Lee et al. [26]. Similarly, Kim et al. [14] reported that Lac. plantarum first appeared at the over-ripening stage $(36 \mathrm{~h}, \mathrm{pH} 4.03$, and acidity $0.88 \%$ ) and increased during mulkimchi fermentation at $30^{\circ} \mathrm{C}$. The difficulty of discrimination between Lac. plantarum and Lac. pentosus was recognized in other LAB studies [27,28]. In addition, Lim et al. [25] also noted the difficulty of discrimination between Lac. plantarum and Lac. brevis by biochemical methods. Additionally, Lac. sakei is and acidophilic and/or acid-producing bacterium, which is phylogenetically close to Lac. plantarum. Thus, two Lactobacillus species, such as Lac. sakei and Lac. plantarum, proportionally increased with the increase in acidity and lactic acid during kimchi fermentation at $8{ }^{\circ} \mathrm{C}$ (low temperature), but Lac. plantarum only increased during kimchi fermentation at 15 and $25^{\circ} \mathrm{C}$ (high temperature). Recently, Hwang et al. [22] reported that results similar to those of this study in mulkimchi fermentation at $8{ }^{\circ} \mathrm{C}$. Conversely, Chin et al. [3] showed that Lac. brevis and Wei. kimchii/cibaria are the predominant species in the initial to mid-stage of fermentation (when kimchi $\mathrm{pH}$ is over 4.0) and Leu. mesenteroides is the only predominant species in the early stage of kimchi fermentation. Cho et al. [4] reported that Wei. koreensis, a psychrophilic bacterium, is probably the dominant species in kimchi produced at $-1{ }^{\circ} \mathrm{C}$ and the predominance of Leuconostoc species, including Leu. citreum, observed after a short preliminary incubation at $15{ }^{\circ} \mathrm{C}$, results in a delay of the rapid outgrowth of Wei. koreensis at $-1{ }^{\circ} \mathrm{C}$. Hwang et al. [22] reported that the reduction in $\mathrm{pH}$ and increment in acidity and lactic acid concentration were observed, these was gradual increase of Wei. koreensis throughout mulkimchi fermentation at $8{ }^{\circ} \mathrm{C}$. Additionally, Lee et al. [9] performed microbial fingerprints by a DGGE to investigate the distribution of microorganisms in kimchi fermented at 10 to $20^{\circ} \mathrm{C}$, and concluded that Wei. confusa, Lac. sakei, Leu. citreum, and Lac. curvatus were dominant. Interestingly, Lac. plantarum, which has been known as a predominant strain in the later stage of fermented vegetables by culture-independent approaches, was not detected by the cultureindependent DGGE analysis. According to one publication [29], Lac. sakei and Leu. mesenteroides are the most predominant LAB in all types of kimchi in the middle stage of fermentation at $20^{\circ} \mathrm{C}$. These results proposed that there could be another important determinant of lactic acid bacterial community in addition to temperature and acidity. Data shown in Figure 1, 2, and 3 strongly indicate that the metabolism of reducing sugar and the production of lactic acid and acetic acid were closely correlated with the growth of Leuconostoc, Lactobacillus, and Weissella.

We attempted to determine whether our culturing method may have missed a portion of the species that actually existed in the kimchi samples, as certain populations may have been unculturable under the experimental conditions. Two pieces of evidence support that predominant species are culturable. First, increases in the total number of viable cells are closely correlated with increases in the levels of fermentation products, including lactic acid and acetic acid. Second, the several reports of microbial diversity in kimchi by culture-independent methods determined that the primary bacterial components include: Leu. citreum, Leu. gasicomitatum, Leu. gelidum, Lac. curvatus, Lac. plantarum, Lac. sakei, Wei. confusa, and Wei. koreensis [5,7-9]. These studies strongly supported our interpretation that the predominant species in kimchi samples can, indeed, be cultured on MRS medium. However, these culture-independent analyses are also somewhat limited. As we showed in a previous study, PCR amplification cannot be strictly correlated with the ratio of target DNA to genomic DNA [30]. As a result, some minor population groups may have been missed. Similar to the majority of molecular techniques for the detection, identification, and classification of bacteria [31,32], multiplex PCR commonly targets the $16 \mathrm{~S}$ rRNA gene, the gene most widely used to infer phylogenetic relationships among bacteria [33]. This gene is sometimes insufficient to distinguish closely related species $[34,35]$; thus, in order to ensure high specificity of multiplex PCR, other genes need to be taken into accounts for primer designation. The results of multiplex PCR show various types of LAB strains detected in the 154 to 506 bp range [5]. The ideal technique would include DNA sequences that were specific for each species in order to obtain a single band per species and the specific bands would differ in size such that the interpretation of band position would be easy [36].

In conclusion, Leu. mesenteroides predominated during optimum- 
ripening when kimchi was fermented at 8,15 , and $25^{\circ} \mathrm{C}$ and $L a c$. sakei and Lac. plantarum rapidly grew in kimchi produced at 8 , 15 , and $25^{\circ} \mathrm{C}$. Experiments also demonstrated that population dynamics are rather sensitive to environmental conditions, including fermentation temperature and acidity. Therefore, the microbial population dynamics characterized in this study may be applicable in the use of microbes for the improved control of kimchi fermentation and preservation.

Acknowledgment This work was supported by Gyeongnam National University of Science and Technology Grant (2020 year), Republic of Korea.

\section{References}

1. Mheen TI, Kwon TW (1984) Effect of temperature and salt concentration on kimchi fermentation. Korean J Food Sci Technol 16: 443-450

2. Kim JM, Song KY, Kim SY, Shin WC, Yoon SS (2004) Effect of eggshell powder on extending the shelf-life of mul-kimchi. Food Sci Biotechnol 13: 136-140

3. Chin WS, Breidt F, Fleming HP, Shin WC, Yoon SS (2006) Identifications of predominant bacterial isolates from the fermenting kimchi using ITS-PCR and partial 16S rDNA sequence analyses. J Microbiol Biotechnol 16: 68-76

4. Cho J, Lee D, Yang C, Jeon J, Kim J, Han H (2006) Microbial population dynamics of kimchi, a fermented cabbage product. FEMS Microbiol Lett 257: 262-267

5. Cho KM, Math RK, Islam SM, Lim WJ, Hong SY, Kim JM, Yun MG, Cho JJ, Yun HD (2009) Novel multiplex PCR for the detection of lactic acid bacteria during kimchi fermentation. Mol Cell Probe 23: 90-94

6. Jeong SH, Lee HJ, Jung JY, Lee SH, Seo HY, Park WS, Jeon CO (2013) Effects of red pepper powder on microbial communities and metabolites during kimchi fermentation. Int J Food Microbiol 160: 252-259

7. Jung JY, Lee SH, Jin HM, Hahn Y, Madsen EL, Jeon CO (2013) Metatranscriptomic analysis of lactic acid bacterial gene expression during kimchi fermentation. Int J Food Microbiol 160: 171-179

8. Kim M, Chun J (2005) Bacterial community structure in kimchi, a Korean fermented vegetable food, as revealed by 16S rRNA gene analysis. Int J Food Microbiol 103: 91-96

9. Lee JS, Heo GY, Lee JW, Oh YJ, Park JA, Park YH, Park YR, Ahn JS (2005) Analysis of kimchi microflora using denaturing gradient gel electrophoresis. Int J Food Microbiol 102: 143-150

10. Park H, Shin H, Holzapfel W (2016) Autoinducer-2 properties of kimchi are associated with lactic acid bacteria involved in its fermentation. Int $\mathrm{J}$ Food Microbiol 225: 38-42

11. Park WS, Moon SW, Lee MK, Ahn BH, Koo YJ, Kim KH (1996) Comparison of fermentation characteristics of the main types of Chinese cabbage kimchi. Food Biotechnol 5: 128-135

12. Kim TW, Jung SH, Lee JY, Choi SK, Park SH, Jo JS, Kim HY (2003) Identification of lactic acid bacteria in kimchi using SDS-PAGE profiles of whole cell proteins. J Microbiol Biotechnol 13: 119-124

13. Bae JW, Rhee SK, Park JR, Chung WH, Nam YD, Lee I, Kim H, Park YH (2005) Development and evaluation of genome-probing microarrays for monitoring lactic acid bacteria. Appl Environ Microbiol 71: 88258835

14. Kim B, Seo WT, Kim MG, Yun HD, Cho KM (2012) Metagenomic lactic acid bacterial diversity during mulkimchi fermentation based on 16S rRNA sequence. J Korean Soc Appl Biol Chem 55: 787-792

15. Elnifro EM, Ashshi AM, Cooper RJ, Klapper PE (2000) Mutiple PCR: optimization and application in diagnostic virology. Clin Microbiol Rev 13: $559-570$

16. Jofré A, Martin B, Garriga M, Hugas M, Pla M, Rodríguez-Lázaro D,
Aymerich T (2005) Simultaneous detection of Listeria monocytogenes and Salmonella by multiplex PCR in cooked ham. Food Microbiol 22: 109-115

17. Jung JY, Lee SH, Kim JM, Park MS, Bae JW, Hahn Y, Madsen EL, Jeon CO (2011) Metagenomic analysis of kimchi, a traditional Korean fermented food. Appl Environ Microbiol 77: 2264-2274

18. Lee M, Song JH, Jung MY, Lee SH, Chang JY (2017) Large-scale targeted metagenomics analysis of bacterial ecological changes in 88 kimchi samples during fermentation. Food Microbiol 66: 173-183

19. Lee SH, Whon TW, Roh SW, Jeon CO (2020) Unraveling microbial fermentation features in kimchi: from classical to meta-omics approaches. Appl Microbiol Biotechnol 104: 7731-7744

20. Miller GL (1959) Use of dinitrosalicylic acid reagent for the determination of reducing sugar. Anal Chem 31: 426-428

21. Haque MA, Lee JH, Cho KM (2015) Endophytic bacterial diversity in Korean kimchi made of Chinese cabbage leaves and their antimicrobial activity against pathogens. Food Cont 56: 24-33

22. Hwang CE, Haque MA, Hong SY, Kim SC, Cho KM (2019) Origin of lactic acid bacteria in mulkimchi fermentation. J Appl Biol Chem 62: $441-446$

23. Choi JY, Kim MY, Lee JH (2002) Reevaluation of the change of Leuconostoc species and Lactobacillus plantarum by PCR during kimchi fermentation. J Microbiol Biotechnol 12: 166-171

24. Cogan TM, Jordan KN (1994) Metabolism of Leuconostoc bacteria. J Dairy Sci 77: 2704-2717

25. Lim CT, Park HK, Han HU (1989) Reevaluation of isolation and identification of Gram-positive bacteria in kimchi. Korean J Microbiol 27: 404-414

26. Lee CW, Ko CY, Ha DM (1992) Microbial changes of the lactic acid bacteria during kimchi fermentation and identification of the isolates. Korean J Appl Microbiol Bioeng 20: 102-109

27. Berthier F, Ehrlich SD (1998) Rapid species identification within two groups of closely related lactobacilli using PCR primers that target the 16S/23S rRNA spacer region. FEMS Microbiol Lett 161: 97-106

28. Schleifer KH, Ehrmann M, Beimfohr C, Brockmann E, Ludwig W, Amann R (1995) Application of molecular methods for the classification and identification of lactic acid bacteria. Int Dairy J 5: 1081-1094

29. Kim TW, Lee JY, Jung SH, Kim YM, Jo JS, Chung DK, Leem HJ, Kim HY (2002) Identification and distribution of predominant lactic acid bacteria in kimchi, a Korean traditional fermented food. J Microbiol Biotechnol 12: 635-642

30. Lee MK, Park WS, Lee BH (2000) Genetic identification of the kimchi strain using PCR-based PepN and 16S rRNA gene sequence. Korean J Food Sci Technol 32: 1331-1335

31. Collins MD, Rodrigues U, Ash C, Aguirre M, Farrow JAE, Martinezmurcia A, Phillips BA, Williams AM, Wallbanks S (1991) Phylogenetic analysis of the genus Lactbacillus and related lactic acid bacteria as determined by reverse-transcriptase sequencing of $16 \mathrm{~S}$ ribosomal-RNA. FEMS Micobiol Lett 77: 5-12

32. Grahn N, Olofsson M, Ellnebo-Svedlund K, Monstein HJ, Jonasson J (2003) Identification of mixed bacterial DNA contamination in broadrange PCR amplification of $16 \mathrm{~S}$ rDNA V1 and V3 variable regions by pyrosequencing of cloned amplicons. FEMS Microbiol Lett 219: 87-91

33. Rosselló-Mora R, Amann R (2001) The species concept for prokaryotes. FEMS Microbiol Rev 25: 39-67

34. Normand P, Ponsonnet C, Nesme X, Neyra M, Simonet P (1996) ITS analysis of prokaryotes. Molecular Microbiol Ecology Manual. Kluwer Academic Publishers, Dordrecht, 1-12

35. Torriani S, Felis GE, Dellaglio F (2001) Differentiation of Lactobacillus plantarum, L. pentosus, and L. paraplantarum by recA gene sequence analysis and multiplex PCR assay with recA gene-derived primers. Appl Environ Microbiol 67: 3450-3454

36. Settanni L, Corsetti A (2007) The use of multiplex PCR to detect and differentiate food-and beverage-associated microorganisms: A review. J Microbiol Meth 69: 1-22 